\title{
Denitrification in a coastal sediment measured in situ by the nitrogen isotope pairing technique applied to a benthic flux chamber
}

\author{
Lars Peter Nielsen*, Ronnie Nøhr Glud** \\ Institute of Biology, Department of Microbial Ecology, University of Aarhus, Ny Munkegade, bygn. 540, \\ DK-8000 Ârhus C, Denmark
}

\begin{abstract}
A free operating benthic flux chamber lander (ELINOR) was used to measure in situ denitrification rates in the Aarhus Bight, Denmark (16 m depth). After insertion of the flux chamber into the sediment ${ }^{15} \mathrm{NO}_{3}{ }^{-}$was automatically injected into the enclosed water phase. After 3 to 4 h of incubation ELINOR was brought back to the surface with an intact water and sediment phase. Dinitrogen was extracted and later analyzed for ${ }^{15} \mathrm{~N}$ enrichment by mass spectrometry. Parallel sediment cores were sampled for laboratory incubation under in situ conditions. In situ denitrification rates in June and November were 350 and $470 \mu \mathrm{mol} \mathrm{N} \mathrm{m} \mathrm{N}^{-2} \mathrm{~d}^{-1}$ respectively, and were not significantly different from the laboratory measured rates of 290 and $500 \mu \mathrm{mol} \mathrm{N} \mathrm{m} \mathrm{N}^{-2} \mathrm{~d}^{-1}$, respectively. Oxygen uptake was $40 \%$ lower in the laboratory incubated cores compared to in situ measurements, apparently due to lowered activity of the dominating species of infauna, the bivalve Abra alba. Nitrate concentrations were low in the bottom water $(<8 \mu \mathrm{M})$ and most of the denitrification activity $(65$ to $100 \%)$ was coupled to nitrification in the sediment. A laboratory test showed that the addition of ${ }^{15} \mathrm{NO}_{3}{ }^{-}$did not significantly impede the reduction rate of the natural unlabelled $\mathrm{NO}_{3}{ }^{-}$The results support the validity of laboratory measurements for coastal waters and demonstrate the potential of combining benthic flux chamber landers and the isotope pairing technique for accurate measurements of denitrification in shelf, deep sea, and freshwater environments.
\end{abstract}

KEY WORDS: Denitrification - Sediment $\cdot$ Benthic lander $\cdot$ Flux $\cdot{ }^{15} \mathrm{~N} \cdot$ Nitrogen $\cdot$ Nitrification

\section{INTRODUCTION}

Primary production in nearshore waters is largely controlled by the availability of combined nitrogen in the phatic zone (Ryther \& Dunstan 1971, Paasche 1988 , ), and the cycling of nitrogen is therefore of prime interest in marine ecology. Denitrification in sediments is the major nitrogen sink in the sea and many attempts to quantify this process have been made (for review see Seitzinger 1988). The most widespread methods are based on laboratory incubations of sediment cores measuring either $\mathrm{N}_{2}$ efflux (Seitzinger et al. 1980), $\mathrm{N}_{2} \mathrm{O}$

\footnotetext{
·E-mail: lpn@pop.bio.aau.dk

- Present address: Max Planck Institute for Marine Microbiology, Celciusstr 1, D-28359 Bremen, Germany
}

accumulation after acetylene inhibition of $\mathrm{N}_{2} \mathrm{O}$ reduction (Sørensen 1978), ${ }^{15} \mathrm{~N}_{2}$ efflux after addition of ${ }^{15} \mathrm{~N}$ tracers (Nishio et al. 1983) or differences of $\mathrm{NO}_{3}^{-}$ fluxes and nitrification rates (Blackburn \& Henriksen 1983). The methods were most recently reviewed by Seitzinger (1990), Koike (1990) and Revsbech \& Sørensen (1990). Also, porewater profiles of nitrogen species have been used for estimating denitrification (Vanderborght et al. 1977).

In situ efflux of $\mathrm{N}_{2}$ from the sea bottom was recently measured using a benthic flux chamber lander (Devol 1991). A long incubation time was needed to detect increase of $\mathrm{N}_{2}$ concentration above the high background level, and oxygen in the chamber was therefore seriously depleted (Archer \& Devol 1992), which probably affected denitrification rates by changing nitrification activity and diffusion of $\mathrm{NO}_{3}{ }^{-}$through the 
oxic zone (Nielsen 1992, Rysgaard et al. 1994). The aim of the present study was to try the new nitrogen isotope pairing technique (Nielsen 1992) in situ and compare the denitrification rates obtained with those obtained by parallel laboratory measurements. The nitrogen isotope pairing technique has generally been shown to be sensitive and robust (Nielsen 1992, 1993, Rysgaard et al. 1993, 1995, Pelegrí et al. 1994, Risgaard-Petersen et al. 1994) and seems to eliminate important shortcomings of traditional core incubation methods (Seitzinger et al. 1993). A known amount of ${ }^{15} \mathrm{NO}_{3}{ }^{-}$is added to water overlying the sediment and the indigenous denitrification of unlabelled $\mathrm{NO}_{3}{ }^{-}$is calculated from the formation of single labelled $\left({ }^{14} N^{15} N\right)$ versus double labelled $\left({ }^{15} N^{15} N\right)$ dinitrogen. The method assumes that addition of ${ }^{15} \mathrm{NO}_{3}{ }^{-}$does not influence denitrification of the natural ${ }^{14} \mathrm{NO}_{3}{ }^{-}$and that the isotopes are uniformly mixed in the denitrification zone (Nielsen 1992). These assumptions were also tested in this study.

\section{MATERIALS AND METHODS}

Study site. The study site at $16 \mathrm{~m}$ depth (Stn 6 , $56^{\circ} 09^{\prime} 10^{\prime \prime} \mathrm{N}, 10^{\circ} 19^{\prime} 20^{\prime \prime} \mathrm{E}$ ) in the Aarhus Bight, Denmark, has recently been the object of several integrated studies of carbon, nutrient and mineral cycling ( $\mathrm{K}$. Richardson \& B. B. Jørgensen unpubl.). The sediment is silty with an organic matter content of 9 to $10 \%(\mathrm{dw})$ and a porosity of $0.81(\mathrm{v} / \mathrm{v})$ for the upper $6 \mathrm{~cm}$. In situ measurements and simultaneous collection of cores for laboratory measurements were done on June 10 and November 24, 1992. An extra set of cores for testing of ${ }^{15} \mathrm{NO}_{3}{ }^{-}$concentration effects was collected on June 19.

In situ procedure. In situ measurements were made with the benthic flux chamber lander 'ELINOR' (Glud et al. 1993, 1995) modified from the BECl-lander (Jahnke \& Christiansen 1989). After release the lander sank to the bottom and the respiration chamber $(30 \mathrm{~cm} \times 30 \mathrm{~cm})$ was forced into the sediment. In this shallow water study the lander remained connected to a buoy at the surface. Optionally the lander can be equipped with buoyancy and automatically discharged ballast for free operation at deeper sites (Glud et al. 1994). Further operations were controlled by a preprogrammed computer unit of the lander. Closure of the chamber lid was triggered by burnwires after $1 \mathrm{~h}$ and the water phase was continuously mixed by a magnetic stirrer attached to the lid ( 9 r.p.m.). This created a diffusive boundary layer thickness of approximately $400 \mu m$ (Glud et al. 1995). The enclosed water column was 9 to $13 \mathrm{~cm}$ high. Oxygen concentrations were monitored continuously by two $\mathrm{O}_{2}$ minisensors (Glud et al. 1995) mounted in the lid. About $10 \mathrm{~min}$ after closure $30 \mathrm{ml}$ of $15 \mathrm{mM}^{15} \mathrm{NO}_{3}$ - in seawater was injected into the waterphase (final conc. 35 and $50 \mu \mathrm{M}$ ) from a spring driven $60 \mathrm{ml}$ plastic syringe activiated by a magnetic switch. During the incubation, water samples of $45 \mathrm{ml}$ were withdrawn at predefined time intervals. The samples were stored in gastight ampoules for Winkler calibration of the electrodes. The $\mathrm{O}_{2}$ concentration of the first samples which were stored in situ during the incubation equaled the bottom water value determined from water samples taken by a Niskin bottle. This indicated that the samples were taken without contamination and that the $\mathrm{O}_{2}$ consumption in the samples could be ignored. Incubation time was up to $3 \mathrm{~h}$, which ensured that $\mathrm{O}_{2}$ was depleted by a maximum of only $25 \%$. At the end of the incubation a burnwire triggered a hydraulic scoop which caught the undisturbed water and sediment phase (approx. $25 \mathrm{~cm}$ deep). ELINOR was withdrawn from the bottom and within $10 \mathrm{~min}$ brought on deck where $20 \mathrm{ml}$ of a $50 \%(\mathrm{w} / \mathrm{w})$ $\mathrm{ZnCl}$ solution was added to the water phase to stop biological activity. A laboratory test showed that $\mathrm{O}_{2}$ penetration in the sediment started to increase within seconds after $Z n$ addition, indicating an instant blockage of respiration processes (data not shown). In case the recovery of the lander is expected to take longer, $\mathrm{ZnCl}$ may also be injected at the bottom using an extra automatic syringe. The lid was opened, the water height measured and water samples for determination of ${ }^{15} \mathrm{~N}_{2}$ accumulation was gently transferred by syringes to $12.4 \mathrm{ml}$ glass vials containing $250 \mu \mathrm{l}$ of the $\mathrm{ZnCl}$ solution. The vials were closed with gastight screw caps with injection septa (Exetainer, Labco) without entrapping any air bubbles. Samples for $\mathrm{NO}_{3}$ analysis were taken in plastic vials. The water phase was always clear as were the recovered time series water samples indicating no significant disturbance of the sediment surface during incubation and recovery of the lander. Eight plexiglass cylinders (inner diameter, i.d. $=5 \mathrm{~cm}$ ) were evenly inserted in the sediment and core samples with 6 to $9 \mathrm{~cm}$ sediment and 5 to $9 \mathrm{~cm}$ water were taken. To extract ${ }^{15} \mathrm{~N}_{2}$ accumulated in the porewater, sediment and water in each core was gently mixed into a slurry from which samples were taken into Exetainers as described above. All sediment in the chamber was sieved ( $0.5 \mathrm{~mm}$ mesh) for the collection of infauna. Oxygen electrode data were transferred from the lander memory into a transportable computer, and $\mathrm{O}_{2}$ fluxes were calculated from the linear decline in $\mathrm{O}_{2}$ concentration during incubation

Laboratory incubations. Sets of 8 sediment cores (j..d. $=5 \mathrm{~cm}$ ) with 5 to $9 \mathrm{~cm}$ sediment and 7 to $12 \mathrm{~cm}$ water phase were taken from box core samples and transferred in thermoboxes to the laboratory within $4 \mathrm{~h}$. Bottom water for incubation was pumped from $0.5 \mathrm{~m}$ above the bottom and transported in plastic 
containers. Winkler samples for determination of $\mathrm{O}_{2}$ concentration in the bottom water were also taken. In the laboratory the sediment cores were opened and immersed in an aquarium with 201 bottom water thermostatted at the in situ temperature $\left( \pm 1^{\circ} \mathrm{C}\right)$. The water column in each core was mixed by small magnetic stirrers driven by an external magnet (30 r.p.m.). This stirring rate created the same diffusive boundary layer thickness of about $400 \mu \mathrm{m}$ as in the flux chamber. The $\mathrm{O}_{2}$ concentration was maintained near in situ levels by gentle purging with a $\mathrm{N}_{2}$ /air gas mixture. Incubation was initiated after about $4 \mathrm{~h}$ by mixing $15 \mathrm{mM}^{15} \mathrm{NO}_{3}{ }^{-}$stock solution into the aquarium to a final concentration of 55 to $76 \mu \mathrm{M}$. The cores were closed with rubber stoppers after $15 \mathrm{~min}$ when complete mixing of bulk water with the water column of each core was ensured.

For testing of $\mathrm{NO}_{3}{ }^{-}$concentration effects ${ }^{15} \mathrm{NO}_{3}^{-}$was added to each individual core to obtain a range of concentrations from 2 to $60 \mu \mathrm{M}^{15} \mathrm{NO}_{3}{ }^{-}$. Samples for initial $\mathrm{O}_{2}$ and $\mathrm{NO}_{3}{ }^{-}$concentrations were taken from the aquarium. Incubation times of 3 to $5.5 \mathrm{~h}$ ensured that $\mathrm{O}_{2}$ was never depleted by more than $25 \%$ in any core. After incubation the stoppers were removed, water samples for $\mathrm{O}_{2}, \mathrm{NO}_{3}{ }^{-}$and ${ }^{15} \mathrm{~N}_{2}$ were rapidly taken as previously described and $250 \mu \mathrm{ZnCl}$ solution was added to each core. Sediment and water phases were mixed and a slurry sample was taken as previously described. Sediment was sieved and infauna collected.

Analysis and calculations. Nitrate was analyzed using the standard method (Grashoff 1983) and $\mathrm{O}_{2}$ was analyzed by Winkler titration. One $\mathrm{ml}$ of the water in the Exetainers was exchanged with $\mathrm{He}$, and dissolved $\mathrm{N}_{2}$ was extracted in the headspace by vigorous shaking. Subsamples of the headspace were withdrawn with syringe and injected into a gas chromatograph in line with a mass spectrometer as described by Nielsen (1992). Water and slurry samples from cores without ${ }^{15} \mathrm{~N}$ added were used as blinds and excess ${ }^{14} \mathrm{~N}^{15} \mathrm{~N}$ and ${ }^{15} \mathrm{~N}^{15} \mathrm{~N}$ concentrations were calculated. Production rates (umol ${ }^{14} \mathrm{~N}^{15} \mathrm{~N}$ or ${ }^{15} \mathrm{~N}^{15} \mathrm{~N} \mathrm{~m}^{-2} \mathrm{~d}^{-1}$ ) were calculated from incubation times, sediment and water volumes and sediment porosity. Time-zero for the incubation was the moment ${ }^{15} \mathrm{NO}_{3}{ }^{-}$was added. Denitrification rates were calculated according to Nielsen (1992). The denitrification rate of ${ }^{15} \mathrm{NO}_{3}{ }^{-}$added to the water (d15w) was obtained from the production rates of the labelled $\mathrm{N}_{2}$ species:

$$
d 15 w=\left({ }^{14} N^{15} N\right)+2\left({ }^{15} N^{15} N\right)
$$

Only a part of the indigenous rate of denitrification (d14) is directly measurable as ${ }^{14} \mathrm{~N}^{13} \mathrm{~N}$ production; the unlabelled part $\left({ }^{14} \mathrm{~N}^{14} \mathrm{~N}\right)$ is not detectable due to high atmospheric background. Therefore d14 was calcu- lated indirectly from d15 and the ratio of ${ }^{15} \mathrm{~N}$ paired with ${ }^{14} \mathrm{~N}\left({ }^{14} \mathrm{~N}^{15} \mathrm{~N}\right)$ versus ${ }^{15} \mathrm{~N}$ paired with ${ }^{15} \mathrm{~N}\left({ }^{15} \mathrm{~N}^{15} \mathrm{~N}\right)$ assuming uniform mixing and random pairing of the isotopes in the denitrification zone (Nielsen 1992):

$$
\mathrm{d} 14=\mathrm{d} 15 \mathrm{w} \times\left({ }^{14} \mathrm{~N}^{15} \mathrm{~N}\right) / 2\left({ }^{15} \mathrm{~N}^{15} \mathrm{~N}\right)
$$

Denitrification of unlabelled $\mathrm{NO}_{3}{ }^{-}$diffusing from the overlying water (d14w) was calculated from d15w assuming a linear relationship between water phase $\mathrm{NO}_{3}$ concentration and denitrification:

$$
\mathrm{d} 14 \mathrm{w}=\mathrm{d} 15 \mathrm{w} \times\left[{ }^{14} \mathrm{NO}_{3}{ }^{-}\right] /\left[{ }^{15} \mathrm{NO}_{3}{ }^{-}\right]
$$

The ${ }^{14} \mathrm{NO}_{3}{ }^{-}$concentrations in the overlying water were measured in water samples taken before addition of ${ }^{15} \mathrm{NO}_{3}{ }^{-}$, while the ${ }^{15} \mathrm{NO}_{3}^{-}$concentrations were measured as the concentration increase in samples taken after addition. Finally denitrification of $\mathrm{NO}_{3}{ }^{-}$produced by nitrification within the sediment $(\mathrm{d} 14 \mathrm{n})$ was calculated by difference:

$$
\mathrm{d} 14 \mathrm{n}=\mathrm{d} 14-\mathrm{d} 14 \mathrm{w}
$$

\section{RESULTS}

Nine cores incubated in the laboratory with different levels of ${ }^{15} \mathrm{NO}_{3}{ }^{-}$showed strict linear correlation between concentration and denitrification of ${ }^{15} \mathrm{NO}_{3}{ }^{-}$ (Fig. 1). The calculated rate of indigenous denitrification (d14) was stable around $300 \mu \mathrm{mol} \mathrm{N} \mathrm{m}^{-2} \mathrm{~h}^{-1}$ at ${ }^{15} \mathrm{NO}_{3}{ }^{-}$concentrations above $10 \mu \mathrm{M}$, below which a distinct decline was evident. The initial concentration of ${ }^{14} \mathrm{NO}_{3}{ }^{-}$in the water phase was small, $0.5 \mu \mathrm{M}$, and the

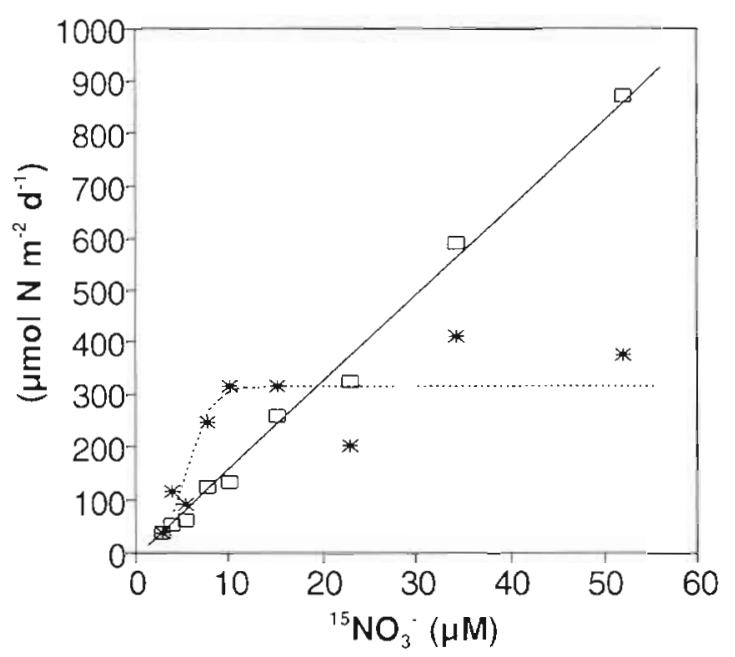

Fig. 1. Effecte of the concentration of ${ }^{15} \mathrm{NO}_{j}{ }^{-}$in the watci col umn on denitrification of ${ }^{15} \mathrm{NO}_{3}^{-}(\mathrm{d} 15 \mathrm{w})$ ( $\square$ ) and estimates of the denitrification of the indigenous ${ }^{14} \mathrm{NO}_{3}{ }^{-}$(d14) (*) in sediment core samples 


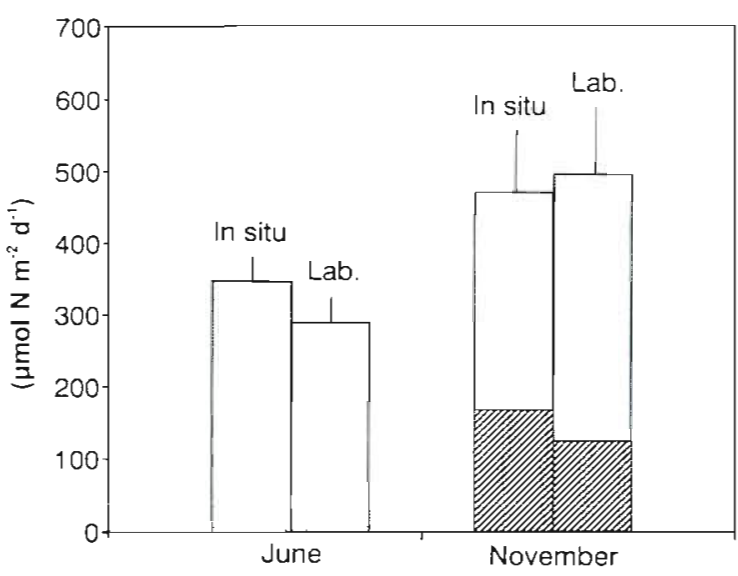

Fig. 2. Comparison of indigenous denitrification rates (d14) estimated from in situ incubations in a benthic flux chamber and laboratory incubations of sediment core samples. Hatched portions of columns represent denitrification of $\mathrm{NO}_{3}{ }^{-}$ from the water column ( $\mathrm{d} 14 \mathrm{w}$ ). Error bars indicate standard deviation for cores (laboratory, $\mathrm{n}=6$ ) or subsamples in the tlux chamber (in situ, $\mathrm{n}=8$ )

contribution of d14w to d14 was only $8 \mu \mathrm{mol} \mathrm{m}^{-2} \mathrm{~h}^{-1}$. which could be ignored.

In situ and laboratory incubations indicated similar rates of denitrification in the sea bottom both in June and November (Table 1, Fig. 2). More than $80 \%$ of the labelled $\mathrm{N}_{2}$ produced during the incubations accumulated in the pore water, the rest being released to the water column (data not shown), and identical standard deviations were found for the cores incubated in the laboratory and for the similar sized subsamples taken in the flux chamber (Fig. 2). Denitrification of $\mathrm{NO}_{3}{ }^{-}$ produced by nitrification within the sediment was similar in June and November and the increased total denitrification rate in November was due to denitrification of $\mathrm{NO}_{3}{ }^{-}$present in the water column in November (Table 1).

Oxygen consumption rates were 40 to $50 \%$ lower in the laboratory compared to those in situ (Table 1.). The average $\mathrm{O}_{2}$ concentration in the laboratory cores was $20 \%$ higher than those in situ in June and $20 \%$ lower in November (Table 1).

\section{DISCUSSION}

Important assumptions of the isotope pairing method were supported by the experiment with different additions of ${ }^{15} \mathrm{NO}_{3}{ }^{-}$to sediment cores. The linear correlation of d $15 \mathrm{w}$ and ${ }^{15} \mathrm{NO}_{3}{ }^{-}$concentration showed that denitrification of $\mathrm{NO}_{3}{ }^{-}$from existing sources is not impeded significantly by addition of extra sources within the investigated concentration range. The independence of added ${ }^{15} \mathrm{NO}_{3}{ }^{-}$was also confirmed by the relatively constant estimate of the rate of denitrification of ${ }^{14} \mathrm{NO}_{3}{ }^{-}$(d 14) for ${ }^{15} \mathrm{NO}_{3}{ }^{-}$concentrations above $10 \mu \mathrm{M}$. Microsensor and model studies have also shown that diffusional supply of $\mathrm{NO}_{3}{ }^{-}$from the oxic zone rather than kinetics of denitrification within the anoxic zone is controlling the process (Christensen et al. 1990, Nielsen et al. 1990).

A key assumption for the calculation of $\mathrm{d} 14$ is a uniform mixing and pairing of the nitrogen isotopes all over the denitrification zone and during the whole incubation (Nielsen 1992). Any non-uniform mixing will increase the formation of homogenous isotope pairs, ${ }^{14} \mathrm{~N}^{14} \mathrm{~N}$ and ${ }^{15} \mathrm{~N}^{15} \mathrm{~N}$, relative to the mixed pair ${ }^{14} \mathrm{~N}^{15} \mathrm{~N}$ and $\mathrm{d} 14$ will be underestimated by the standard calculation. Non-uniform mixing will occur in heterogenous sediments with different spots having different activity of nitrification and denitrification. Isotopic dilution of ${ }^{15} \mathrm{NO}_{3}{ }^{-}$in the water phase due to efflux of ${ }^{14} \mathrm{NO}_{3}{ }^{-}$from the sediment during incubation also causes non-uniform isotope mixing. Bioturbation may similarly induce spatial and temporal heterogeneity in isotope mixing The actual significance of non-uniform isotope mixing, however, is readily tested by incubations with a range of ${ }^{15} \mathrm{NO}_{3}{ }^{-}$concentrations as done in this study. Higher concentrations of ${ }^{15} \mathrm{NO}_{3}{ }^{-}$minimize the potential underestimation of the denitrification of ${ }^{14} \mathrm{NO}_{3}{ }^{-}(\mathrm{d} 14)$ because a larger fraction of the ${ }^{14} \mathrm{NO}_{3}{ }^{-}$ being denitrified is paired with ${ }^{15} \mathrm{NO}_{3}{ }^{-}$and directly measured as ${ }^{14} \mathrm{~N}^{15} \mathrm{~N}$, while less ends up as ${ }^{14} \mathrm{~N}^{14} \mathrm{~N}$ which is the indirectly estimated part of d14 (Nielsen 1992, Pelegrí et al. 1994, Rysgaard et al. 1995). Underestimates of $\mathrm{d} 14$ at low ${ }^{15} \mathrm{NO}_{3}{ }^{-}$levels is indeed demonstrated by the data in Fig. 1 where the calculated d 14

Table 1. Incubation conditions and measured rates of $\mathrm{O}_{2}$ uptake and denitrification in situ and in the laboratory on June 10 and November 24, 1992

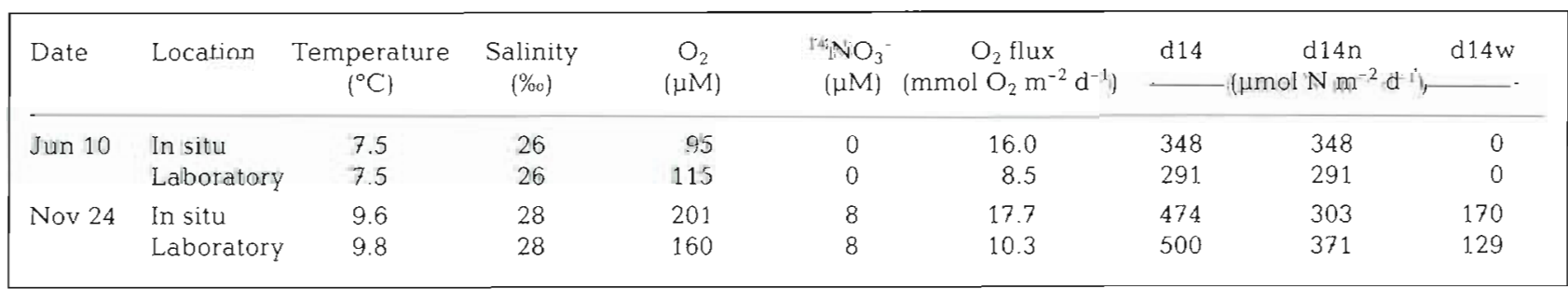


rate drops off at ${ }^{15} \mathrm{NO}_{3}{ }^{-}$concentrations below $10 \mu \mathrm{M}$. The calculated d 14 rate does not increase at concentrations above $10 \mu \mathrm{M}$, thus confirming that the standard levels of 20 to $80 \mu \mathrm{M}^{15} \mathrm{NO}_{3}{ }^{-}$used here and in other studies (Nielsen 1992) eliminated the effect of non-uniform isotope pairing. A similar concentration test in a very intensively bio-ventilated estuarine sediment suggested ${ }^{15} \mathrm{NO}_{3}{ }^{-}$concentrations between 60 and $300 \mu \mathrm{M}$ to be applied for optimal determination of $\mathrm{d} 14$ (Pelegrí et al. 1994). After injection of ${ }^{15} \mathrm{NO}_{3}{ }^{-}$it takes some time before diffusion has established a steady state ${ }^{15} \mathrm{NO}_{3}{ }^{-}$profile, and it is important that this period is short as compared to the total incubation time. In our case the $\mathrm{O}_{2}$ penetration depth was less than $2.5 \mathrm{~mm}$ (J. Gundersen unpubl. data), which ensured that an equal distribution of the 2 species of $\mathrm{NO}_{3}{ }^{-}$was established relatively shortly after injection. In any case, the test of uniform isotope mixing discussed above will also indicate if establishment of the $\mathrm{NO}_{3}{ }^{-}$profiles is a problem.

The similar rates of denitrification and the low standard deviations (Fig. 2) obtained by measurements in situ and in the laboratory were promising and indicated that both the denitrification process and the method are relatively sturdy. Blackburn \& Henriksen (1983) calculated denitrification rates from differences of nitrifications rates and $\mathrm{NO}_{3}^{-}$fluxes at a nearby station in the bight. They estimated rates of 500 and $300 \mu \mathrm{mol} \mathrm{m} \mathrm{m}^{-2} \mathrm{~d}^{-1}$ in July and November 1979. These rates are quite similar to the rates reported here. Jensen et al. (1988) measured denitrification at 3 other stations in the bight using the acetylene block technique and the rate estimates varied considerably, from 90 to $800 \mu \mathrm{mol} \mathrm{N} \mathrm{m} \mathrm{N}^{-2} \mathrm{~d}^{-1}$ in July 1985 and from 60 to $280 \mu \mathrm{mol} \mathrm{N} \mathrm{m}^{-2} \mathrm{~d}^{-1}$ in November 1985. Acetylene also blocks nitrification and Seitzinger et al. (1993) showed that in a lake sediment the technique could not capture coupled nitrification-denitrification. The $\mathrm{NO}_{3}^{-}$concentration in the bottom water in July 1985 was $8 \mu \mathrm{M}$ (M. H. Jensen pers. comm.) and the denitrification activity measured by the acetylene block technique might in this case be ascribed to diffusion of $\mathrm{NO}_{3}{ }^{-}$from the water column. In November 1985, however, the $\mathrm{NO}_{3}{ }^{-}$concentration was $4 \mu \mathrm{M}$ and yet the denitrification estimates were significant. In November $1985 \mathrm{a}$ deeper $\mathrm{O}_{2}$ penetration may imply that the pool of $\mathrm{NO}_{3}{ }^{-}$ in the sediment arising from nitrification is larger and may contribute significantly to the denitrification activity after inhibition of nitrification. The efficiency of the acetylene block technique under varying conditions still needs further investigations.

The dominating infauna at the station was the bivalve $A b r a$ alba 1400 ind. $\mathrm{m}^{-2}$ with an average length of $15 \mathrm{~mm}$ in June, and 300 ind. $\mathrm{m}^{-2}$ with an average length of $10 \mathrm{~mm}$ in November). The higher $\mathrm{O}_{2}$ uptake rates measured in situ as compared to the rates mea- sured in the laboratory were partly caused by inactivation of the infauna upon sampling and partly by lower density of animals in the sampled cores. It was observed that only a few of the bivalves in the cores had their siphons extending to the surface and were thereby actively respiring. This was generally observed when cores for incubations were brought back to the laboratory (J Gundersen \& R. Glud unpubl.). The buried bivalves pump respiration water through siphons extending to the sediment surface and the sediment surrounding the siphon may not be oxygenated or otherwise affected. Therefore no differences in denitrification activity were observed between the laboratory and the in situ incubation even though the $\mathrm{O}_{2}$ uptake in situ was significantly higher (Table 1). Some burrow dwelling animals are known to stimulate nitrification and denitrification considerably by pumping water with $\mathrm{O}_{2}$ and $\mathrm{NO}_{3}{ }^{-}$into the sediment (Henriksen et al. 1980, Aller 1988, Kristensen et al. 1991) and if collection of sediment cores impedes their activity, gross underestimates of in situ denitrification activity might be obtained by laboratory incubations.

This study was performed at a shallow site $(16 \mathrm{~m})$ where pressure changes during recovery are not likely to influence biological processes. At larger depths, where decompression during sediment sampling may disturb biological activity and porewater chemistry (Jahnke et al. 1989, Glud et al. 1995), the combination of in situ flux chambers and isotope pairing technique presented here seems optimal for measuring denitrification. With increased $\mathrm{O}_{2}$ penetration depth it takes more time to establish a steady state gradient of ${ }^{15} \mathrm{NO}_{3}{ }^{-}$ in the sediment. The incubation time and the height of the enclosed water phase therefore have to be increased in parallel with $\mathrm{O}_{2}$ penetration depth. Heating of sediment cores during recovery can affect measured metabolic rates and porewater profiles (Glud et al. 1995). In situations where a transient heating of the sediment cores can be expected either in the water column or during extended recovery time or time on deck, injection of $\mathrm{ZnCl}$ into the incubation chamber can be performed before recovery. The in situ technique may also be optimal in many limnic systems with surface located denitrification where ebullition of methane bubbles makes it impossible to sample undisturbed sediment cores even from shallow depth.

Acknowledgements. We thank Hans Jensen and Sten P. Andersen for their skillful technical assistance in operation of ELINOR and during the laboratory work, and Anni Glud for the construction of minielectrodes used on ELINOR. This wulk was suppiputied hy the Nututional Agency of Envircnmon. tal Protection in Denmark in relation to HAV90-Marine Research Program in Denmark (contract nos. 3.27, 3.21 and 1.23). 


\section{LITERATURE CITED}

Aller RC (1988) Benthic faund and biogeochemical processes in marine sediments; the role of burrow structures. In: Blackburn TH, Sørensen J (eds) Nitrogen cycling in coastal marine environments. John Wiley and Sons Ltd, Chichester, p 301-338

Archer D, Devol A (1992) Benthic oxygen fluxes on the Washington shelf and slope: a comparison of in situ microelectrode and chamber flux measurements. Limnol Oceanogr $37: 614-629$

Blackburn TH, Henriksen K (1983) Nitrogen cycling in different types of sediments from Danish. waters. Limnol Oceanogr 28:477-493

Christensen PB, Nielsen LP, Sørensen J, Revsbech NP (1990) Denitrification in nitrate-rich streams: diel and seasonal variation related to benthic oxygen metabolism. Limnol Oceanogr 35:640-651

Devol AH (1991) Direct measurement of nitrogen gas fluxes from continental shelf sediments. Nature 349:319-321

Glud RN, Gundersen JK, Jargensen BB, Revsbech NP, Schultz HD (1994) Diffusive and total oxygen uptake of deep sea sediments in the Suuth East Atiantic Ocean: in situ and laboratory measurements. Deep Sea Res 41: $1767-1788$

Glud RN, Gundersen JK, Revsbech NP, Jørgensen BB (1993) In situ measurements of total and diffusive oxygen uptake of scdiments. In: Guerrero R, Pedrós-Alió $\mathrm{C}$ (ecis) Trends in microbial ecology. Spanish Society for Microbiology, Barcelona, p 427-430

Glud RN, Gundersen JK, Revsbech NP, Jørgensen BB, Hüttel $M$ (1995) Calibration and performance of the stirred flux chamber from the benthic lander ELINOR. Deep Sea Res 42:1029-1042

Grashoff K, Erhardt M, Kremling K (1983) Methods of seawater analysis, 2nd revised and extended edn. Verlag Chemie, Weinheim

Henriksen K, Hansen JI, Blackburn TH (1980) The influence of benthic infauna on exchange rates of inorganic nitrogen between sediment and water Ophelia (Suppl) 1:249-256

Jahnke RA, Christiansen MB (1989) A free-vehicle benthic chamber instrument for sea floor studies. Deep Sea Res 36 : $625-637$

Jahnke RA, Emerson SR, Reimers CE, Schuffert J, Ruttenberg K, Archer D (1989) Benthic recycling of biogenic debris in. the eastern tropical Atlantic Ocean. Geochim Cosmochim Acta 53:2947-2960

Jensen MH. Andersen TK, Sørensen J (1988) Denitrification in coastal bay sediment: regional and seasonal variation in Aarhus Bight, Denmark. Mar Ecol Prog Ser 48:155-162

Koike I (1990) Measurement of sediment denitrification using ${ }^{15} \mathrm{~N}$ tracer method. In: Revsbech NP, Sørensen J (eds) Denitrification in soil and sediment. FEMS Symposium no. 56. Plenum Press, New York, p 291-300

Kristensen E, Jensen MH, Aller RC (1991) Direct measurement of dissolved inorganic nitrogen exchange and denitrification in individual polychaete (Nereis virens) burrows. J Mar Res 49:355-377

Nielsen LP (1992) Denitrification in sediment determined from nitrogen isotope pairing. FEMS Microbiol Ecol 86 $357-362$

Nielsen LP (1993) Denitrification in microbial gradient communities. fn: Guerrero R, Pedrós-Alió $C$ (eds) Trends in

This article was submitted to the editor microbial ecology. Spanish Society for Microbiology Barcelona, p 153-156

Nielsen LP, Christensen PB, Revsbech NP, Sørensen J (1990) Denitrification and photosynthesis in stream sediment studied with microsensor and whole-core techniques. Limnol Oceanogr 35:1135-1144

Nishio T, Koike I, Hattori A (1983) Estimates of denitrification and nitrification in coastal and estuarine sediments. Appl Environ Microbiol 45:444-450

Paasche E (1988) Pelagic primary production in nearshore waters. In: Blackburn $\mathrm{TH}$, Sørensen $\mathrm{J}$ (eds) Nitrogen cycling in coastal marine environments. John Wiley and Sons Ltd, Chichester, p 33-57

Pelegrí SP, Nielsen LP, Blackburn TH (1994) Denitrification in estuarine sediment stimulated by the irrigation activity of the amphipod Corophium volutator. Mar Ecol Prog Ser 105:285-290

Revsbech NP, Sørensen J (1990) Combined use of the acetyJene inhibition technique and microsensors for quantification of denitrification in sediments and biofilms. In: Revsbech NP, Sorensen J (eds) Denitrification in soil and sediment. FEMS Symposium No 56. Plenum Press, New York, p 291-300

Risgaard-Petersen N, Rysgaard S, Nielsen LP, Revsbech NP (1994) Diurnal variation of denitrification and nitrification in sediments colonized by benthic microphytes. Limnol Oceanogr 39:573-579

Rysgaard S, Christensen $\mathrm{P}, N_{1}$ elsen LP (1995) Seasonal variation in nitrification and denitrification in estuarine sediment colonized by benthic microalgae and bioturbating infauna. Mar Ecol Prog Ser 126:111-121

Rysgaard S, Risgaard-Petersen N, Nielsen LP, Revsbech NP (1993) Nitrification and denitrification in lake and estuarine sediments measured by ${ }^{15} \mathrm{~N}$ dilution techniques and isotope painng. Appl Environ Microbiol 59: $2093-2098$

Rysgaard S, Risgaard-Petersen $N$, Sloth NP, Jensen $K$ Nielsen LP (1994) Oxygen regulation of nitrification and denitrification in sediments. Limnol Oceanogr 39(7): $1643-1652$

Ryther JH, Dunstan WM (1971) Nitrogen, phosphorus, and eutrophication in the coastal marine environment. Science 171:1008-1011

Seitzinger SP (1988) Denitrification in freshwater and coastal marine ecosystems: ecological and geochemical significance. Limnol Oceanogr 33:702-724

Seitzinger SP (1990) Denitrification in aquatic sediments. In Revsbech NP, Sorensen J (eds) Denitrification in soil and sediment. FEMS Symposium No 56. Plenum Press, New York, p 291-300

Seitzinger SP, Nielsen LP, Caffrey J, Christensen PB (1993) Denitrification measurements in aquatic sediments: a comparison of three methods. Biogeochemistry 23: $147-167$

Seitzinger SP, Nixon SW, Pilson MEQ, Burke S (1980) Denitrification and $\mathrm{N}_{2} \mathrm{O}$ production in nearshore marine sediments. Geochim Cosmochim Acta 44:1853-1860

Sørensen J (1978) Denitrification rates in a marine sediment as measured by the acetylene inhibition technique. Appl Environ Microbiol 36:139-143

Vanderborght JP, Wollast R, Billen G (1977) Kinetic models of diagenesis in disturbed sediments. Part 2. Nitrogen diagenesis. Limnol Oceanogr 22:794-803

Manuscript first received: December 6, 1994

Revised version accepted: March 8, 1996 